OPEN ACCESS

Edited by:

Heiko Mühl,

Goethe University Frankfurt, Germany

Reviewed by:

Angelo A. Manfredi,

Vita-Salute San Raffaele University,

Italy

Paolo Sfriso,

University of Padova, Italy

*Correspondence:

Pierre Miossec

miossec@univ-lyon1.fr

Specialty section:

This article was submitted to Inflammation,

a section of the journal

Frontiers in Immunology

Received: 21 September 2016 Accepted: 02 November 2016 Published: 17 November 2016

Citation:

Noack M, Ndongo-Thiam N and Miossec $P$ (2016) Evaluation of Anti-inflammatory Effects of Steroids and Arthritis-Related Biotherapies in an In Vitro Coculture Model with Immune Cells and Synoviocytes.

Front. Immunol. 7:509.

doi: 10.3389/fimmu.2016.00509

\section{Evaluation of Anti-inflammatory Effects of Steroids and Arthritis-Related Biotherapies in an In Vitro Coculture Model with Immune Cells and Synoviocytes}

\author{
Mélissa Noack, Ndiémé Ndongo-Thiam and Pierre Miossec* \\ Immunogenomics and Inflammation Research Unit, EA 4130, Edouard Herriot Hospital, Hospices Civils de Lyon and \\ University Claude Bernard Lyon 1, Lyon, France
}

Background: During rheumatoid arthritis (RA), steroids and biotherapies are used alone and combined. Efficacy has been established in clinical trials but their differential effects at the cellular level are less documented. The aim was to study these cellular effects using an in vitro model with synoviocytes interacting with peripheral blood mononuclear cells (PBMC) to reproduce the interactions in the RA synovium.

Methods: Activated-PBMC were cocultured with RA synoviocytes during $48 \mathrm{~h}$. A doseresponse of methylprednisolone (MP) was tested and different biotherapies (Infliximab, Etanercept, Adalimumab, Tocilizumab, Abatacept, and Rituximab) were added alone or in combination with MP. Cytokine production (IL-17, IL-6, IL-1 $\beta$, IFN- $\gamma$ and IL-10) was measured by ELISA.

Results: Addition of MP to cocultures inhibited the production of all cytokines. The response to the biotherapies alone was treatment-dependent. IL-17 production was inhibited only by Tocilizumab $(\rho=0.004)$, while IL-6 was decreased only by Infliximab $(p \leq 0.002)$. IL-1 $\beta$ level was affected in all conditions ( $p \leq 0.03)$. IFN- $\gamma$ production was mainly decreased by Infliximab $(\rho=0.004)$ and IL-10 by Infliximab and Tocilizumab $(p \leq 0.004)$. The combination MP and biotherapies did not induce an additional effect on pro-inflammatory cytokine inhibition. The combination MP and biotherapies induced a higher IL-10 secretion than MP alone, mainly with Rituximab.

Conclusion: Steroids inhibited the secretion of all cytokines, and low doses were as potent. The anti-inflammatory effect of biotherapies was dependent on their mechanism of action. MP and biotherapy combination did not enhance the inhibitory effect on pro-inflammatory cytokines but could have a beneficial effect by increasing IL-10 production.

Keywords: methylprednisolone, biotherapies, rheumatoid arthritis, cell interaction, pro-inflammatory cytokines 


\section{INTRODUCTION}

Rheumatoid arthritis (RA) is a chronic inflammatory disease leading to joint destruction (1). Even if its etiology is not yet clarified, different treatments are available to treat the clinical symptoms. Steroids (also named glucocorticoids or corticosteroids) are the oldest and the most classical anti-inflammatory therapy used for many chronic inflammatory diseases other than RA. They act by inhibiting multiple inflammatory genes (encoding cytokines, chemokines, etc.) that are activated during chronic inflammation (2-4). However, their use is associated with adverse events mainly infections specifically at high dose. Moreover, non-responsiveness or resistance can be observed (5). Another key drug is methotrexate (MTX), the most common treatment of RA. MTX improves clinical parameters in RA patients but severe adverse events could lead to discontinuation (6-8).

The heterogeneity of the response to steroids and MTX has led to a combination therapy with biotherapies. In RA, anti-TNF inhibitors are the first and most used biotherapy. Many studies have described the improvement of symptoms and physical functions (9). Nevertheless, adverse events, mainly elevated risk of infections (10), are known and prevention measures are in place. Current studies focus on the clinical level of treatment efficacy, but the mode of action at the cellular level is less documented.

In the RA joint synovium, the inflammation leads to the recruitment of immune cells that interact with local mesenchymal cells as synoviocytes. These interactions contribute to the chronicity of inflammation, notably by increasing the pro-inflammatory cytokine production and the cell survival of synoviocytes (11-13). In our previous studies, the effects of cell interactions on proinflammatory cytokine production were studied using an in vitro model of coculture between mesenchymal cells and peripheral blood mononuclear cells (PBMC). These studies showed that cell interactions were critical for massive pro-inflammatory cytokine secretion. The use of an autologous system validated this model as mimicking the in vivo situation $(14,15)$.

Herein, in the RA inflammatory context, the aim was to compare the effects of all the current biotherapies against TNF, IL-6, CD20, and CTLA4, with or without steroids by using this in vitro cell-cell interaction model looking at cytokine production.

\section{MATERIALS AND METHODS}

\section{Samples}

Rheumatoid arthritis synoviocytes were obtained from synovial tissue of RA patients undergoing joint surgery and who fulfilled the American College of Rheumatology criteria for RA (16). Synovial tissue was minced into small pieces and then adhered in 6-well plates in Dulbecco's modified Eagle's medium (DMEM; Eurobio, Courtaboeuf, France), supplemented with 10\% fetal bovine serum (FBS; Life Technologies, Carlsbad, USA), 2mM L-glutamine, and $100 \mathrm{U} / \mathrm{ml}$ penicillin/streptomycin. Cells were maintained at $37^{\circ} \mathrm{C}$ in a humidified $5 \%$ carbon dioxide incubator and used between passages 4 to 9. PBMC from healthy donors were isolated by Ficoll-Hypaque (Eurobio, Courtaboeuf, France) density-gradient centrifugation. Each individual signed an informed consent form. The protocol was approved by the Ethics Committee of the Hospitals of Lyon for the protection of persons participating in biomedical research under number AC-2010-11-64.

\section{Coculture Assays}

Coculture was initiated by seeding RA synoviocytes overnight in 96-well plates at a density of $2 \times 10^{4}$ cells/well in RPMI 1640 medium (Eurobio, Courtaboeuf, France) supplemented with $10 \%$ human $\mathrm{AB}$ serum, $2 \mathrm{mM}$ L-glutamine, and $100 \mathrm{U} / \mathrm{ml}$ penicillin/streptomycin (complete RPMI). The next day, healthy PBMC $\left(1 \times 10^{5}\right.$ cells/well $)$ were pre-incubated in complete RPMI with or without different treatments and then seeded corresponding to 5:1 ratio, in the presence of phytohemagglutinin (PHA, $5 \mu \mathrm{g} / \mathrm{ml}$ ). After $48 \mathrm{~h}$, supernatants and PBMC were collected for analysis (17).

\section{Treatments}

A dose-response of Methylprednisolone (MP) was done with 0 , $0.001,0.01,0.1,1$, and $10 \mu \mathrm{g} / \mathrm{ml}$. The concentration of $0.01 \mu \mathrm{g} / \mathrm{ml}$ was used in combination with biotherapies. Two concentrations of biotherapies were used in coculture, 10 and $100 \mu \mathrm{g} / \mathrm{ml}$. Infliximab (Remicade, anti-TNF, Merk), Tocilizumab (Roactemra, anti-IL-6 receptor, Roche-Chugai), Abatacept (Orencia, CTLA4 Ig, BMS), Rituximab (Mabthera, anti-CD20, Roche), Etanercept (Enbrel, anti-TNF, Amgen), and Adalimumab (Humira, anti-TNF, Abbvie) were tested.

\section{Enzyme-Linked Immunosorbent Assays}

IL-17A, IL-6, IL-1 $\beta$, IFN- $\gamma$, and IL-10 production was evaluated from culture supernatants with commercially available Duoset enzyme-linked immunosorbent assays (ELISA) kits, according to the manufacturer's instructions (R\&D system, Minneapolis, MN, USA).

\section{Statistical Analysis}

Statistical analyses were performed using paired Wilcoxon test. All analyses were performed with Graph Pad Prism 6 software. $p$ values less than or equal to 0.05 were considered as significant.

\section{RESULTS}

\section{Principle of the In Vitro Model}

During chronic inflammatory arthritis, immune cells infiltrate the inflammatory synovium and interact with local mesenchymal cells, as synoviocytes. This promotes the secretion of various cytokines and chemokines. To mimic this event, an in vitro model of coculture was used. In the RA context, synoviocytes from patients were cultured in the presence of activated-PBMC. These cell-cell interactions lead to massive cytokine production, compared to PBMC alone. In control condition, the cell contact between synoviocytes and healthy resting-PBMC is sufficient to induce IL- 6 and IL-1 $\beta$ production. Nevertheless, a high IL-17 secretion is only obtained in coculture with activated-PBMC. This model was validated by using an autologous system, that is PBMC and synoviocytes from the same RA patients (14). Using 
this model, the effect of treatments on cytokine production resulting from cell interactions could be studied (Figure 1).

\section{Effects of Methylprednisolone}

The effect of MP was evaluated in the coculture system, using a dose-response curve. Different concentrations of MP were tested: $0,0.001,0.01,0.1,1$, and $10 \mu \mathrm{g} / \mathrm{ml}$. The impact on proand anti-inflammatory cytokine production was measured in the supernatants of cultures after $48 \mathrm{~h}$. As observed in Figure 2, IL-17 secretion was significantly decreased from $0.1 \mu \mathrm{g} / \mathrm{ml}(62.3 \pm 24.7$ vs. $112.8 \pm 33.8 \mathrm{pg} / \mathrm{ml}, p=0.03)$, but there was already a decreased production starting from $0.01 \mu \mathrm{g} / \mathrm{ml}(76.6 \pm 27.8$ vs. $112.8 \pm 33.8 \mathrm{pg} / \mathrm{ml}, p=0.06)$. The inhibition followed a dose-response. IL- 6 , IL- $1 \beta$, and IFN- $\gamma$ production significantly decreased starting with the lowest concentration of $0.001 \mu \mathrm{g} /$ $\mathrm{ml}(234.7 \pm 30.2$ vs. $291.8 \pm 20.2 \mathrm{ng} / \mathrm{ml}$, for IL-6; $90.4 \pm 31.7$ vs. $230.5 \pm 77.8 \mathrm{pg} / \mathrm{ml}$, for IL- $1 \beta, p=0.008 ; 234.4 \pm 136.5$ vs. $552.3 \pm 217.6 \mathrm{pg} / \mathrm{ml}$, for IFN- $\gamma, p=0.03)$. The dose effect was clear for IL- 6 secretion and almost for IL-1 $\beta$; nevertheless, for IFN- $\gamma$, the maximum effect was reached from the lowest concentration.

If MP inhibited well the production of pro-inflammatory cytokines, the secretion of the anti-inflammatory cytokine IL-10 was also inhibited by the addition of MP. This decreased production was significant from the lowest concentration of $0.001 \mu \mathrm{g} / \mathrm{ml}$ $(32.0 \pm 12.8$ vs. $70.8 \pm 23.6 \mathrm{pg} / \mathrm{ml}, p=0.02)$ and was not clearly dose-dependent.

These results confirmed the anti-inflammatory potential of $\mathrm{MP}$ in in vitro system, but showed that MP also decreased the production of IL-10.

\section{Effects of Biotherapies Alone}

The effects of the current biotherapies for RA treatment were first tested alone. After preliminary experiments, two doses, 10 and
$100 \mu \mathrm{g} / \mathrm{ml}$, were selected and tested for their effect on cytokine production. As shown in Figure 3, the effects of the addition of biotherapies in coculture were measured on the production of the pro-inflammatory cytokines IL-17, IL-6, IL-1 $\beta$, and IFN- $\gamma$ and the anti-inflammatory cytokine IL-10.

Infliximab is a monoclonal antibody that binds TNF. Infliximab decreased the production of IL-17 at $10 \mu \mathrm{g} / \mathrm{ml}$, without reaching significance $(78.5 \pm 22.1$ vs. $94.8 \pm 26.1 \mathrm{pg} /$ $\mathrm{ml}, p=0.07$, Figure 3A) and also at $100 \mu \mathrm{g} / \mathrm{ml}(70.3 \pm 24.3 \mathrm{vs}$. $94.8 \pm 26.1 \mathrm{pg} / \mathrm{ml}, p=0.055$, Figure $3 \mathrm{~A})$. On the other hand, IL-6 production was decreased by around $30-35 \%$, without a clear dose-response $(223.7 \pm 23.1$ vs. $321.1 \pm 30.1 \mathrm{ng} / \mathrm{ml}$, for $10 \mu \mathrm{g} /$ $\mathrm{ml}, p=0.001 ; 209.2 \pm 27.5$ vs. $321.1 \pm 30.1 \mathrm{ng} / \mathrm{ml}$, for $100 \mu \mathrm{g} /$ $\mathrm{ml}, p=0.002$, Figure 3A). The secretion of IL- $1 \beta$ and IFN- $\gamma$ was the most inhibited by the addition of Infliximab, with a decrease around $60-70 \%(100.8 \pm 28.1 \mathrm{vs} .250 .7 \pm 66.7 \mathrm{pg} / \mathrm{ml}$, for $10 \mu \mathrm{g} / \mathrm{ml}$ and $74.5 \pm 26.8$ vs. $250.7 \pm 66.7 \mathrm{pg} / \mathrm{ml}$, for $100 \mu \mathrm{g} / \mathrm{ml}$, for IL- $1 \beta$, $p=0.002 ; 166.0 \pm 67.9$ vs. $532.0 \pm 163.9 \mathrm{pg} / \mathrm{ml}$, for $10 \mu \mathrm{g} / \mathrm{ml}$ and $158.0 \pm 55.9$ vs. $532.0 \pm 163.9 \mathrm{pg} / \mathrm{ml}$, for $100 \mu \mathrm{g} / \mathrm{ml}$, for IFN- $\gamma$, $p=0.004$, Figure 3A). Furthermore, Infliximab also decreased by about $30 \%$ the production of IL-10 (46.3 $\pm 18.7 \mathrm{vs.} 62.8 \pm 17.5 \mathrm{pg} /$ $\mathrm{ml}$, for $10 \mu \mathrm{g} / \mathrm{ml}, p=0.05 ; 38.0 \pm 16.2$ vs. $62.8 \pm 17.5 \mathrm{pg} / \mathrm{ml}$, for $100 \mu \mathrm{g} / \mathrm{ml}, p=0.002$, Figure 3A).

Tocilizumab is a monoclonal antibody that binds the IL- 6 receptor. Tocilizumab inhibited significantly the production of IL-17 either at $10 \mu \mathrm{g} / \mathrm{ml}(62.0 \pm 19.4 \mathrm{vs} .94 .8 \pm 26.1 \mathrm{pg} / \mathrm{ml}, p=0.004$, Figure $3 \mathrm{~B})$ or at $100 \mu \mathrm{g} / \mathrm{ml}(53.7 \pm 16.7$ vs. $94.8 \pm 26.1 \mathrm{pg} / \mathrm{ml}$, $p=0.004$, Figure 3B), with a dose effect $(p=0.04$, Figure $3 B$ ). While IL- $1 \beta$ production was also significantly decreased by the addition of Tocilizumab (106.5 \pm 30.8 vs. $250.7 \pm 66.7 \mathrm{pg} / \mathrm{ml}$, for $10 \mu \mathrm{g} / \mathrm{ml}$; $105.1 \pm 30.4$ vs. $250.7 \pm 66.7 \mathrm{pg} / \mathrm{ml}$, for $100 \mu \mathrm{g} / \mathrm{ml}$, $p=0.002$, Figure 3B), without a clear dose effect, the secretion of IL-6 was similar to the control $(293.4 \pm 33.1$ vs. $321.1 \pm 30.1 \mathrm{ng} /$ $\mathrm{ml}$ for $10 \mu \mathrm{g} / \mathrm{ml} ; 293.3 \pm 34.9$ vs. $321.1 \pm 30.1 \mathrm{ng} / \mathrm{ml}$, for $100 \mu \mathrm{g} /$

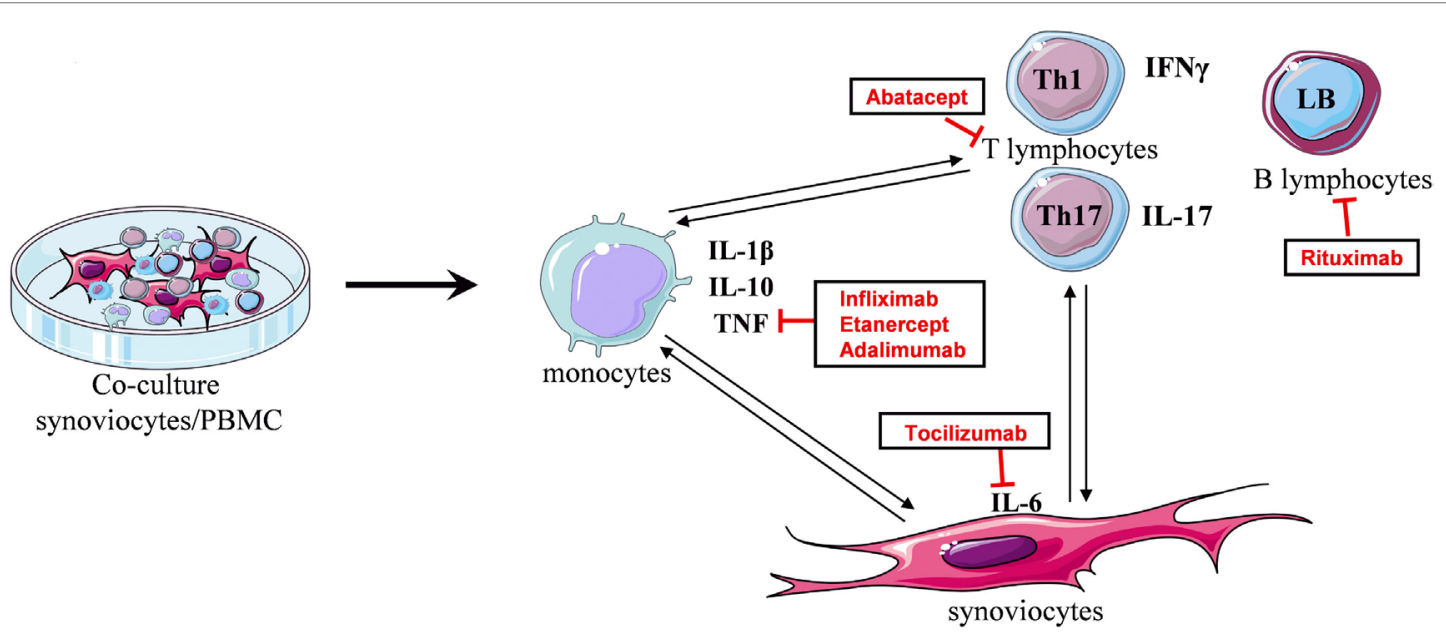

FIGURE 1 | Principle of the in vitro coculture model. Coculture between synoviocytes and activated-PBMC leads to cell interactions promoting the secretion of cytokines. Cell-cell contact induces IL-1 $\beta$, TNF, or IL-10 production, mainly by monocytes. In turn, TNF and IL-1 $\beta$ stimulate synoviocytes to produce IL-6. Secreted cytokines influence T lymphocyte differentiation, as IL-6 and IL-1 $\beta$ for Th17 cells, and then interactions with synoviocytes promote the release of their cytokine, as IL-17 which, in turn, stimulates synoviocytes. The coculture reproduces the cell interactions existing in the inflammatory site and the cytokine environment. Using this model, the effect of treatments on cytokine production resulting from cell interactions can be studied. 


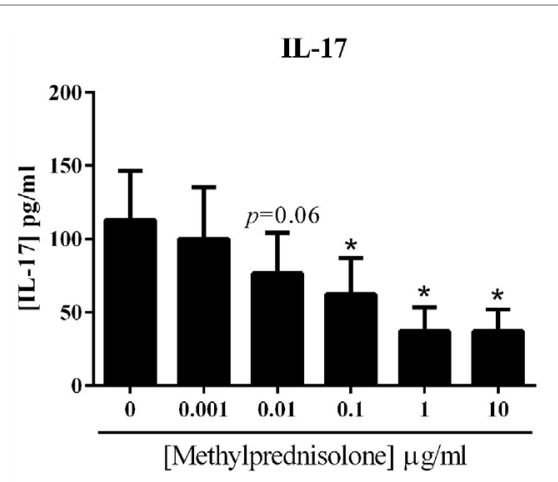

IFN- $\gamma$

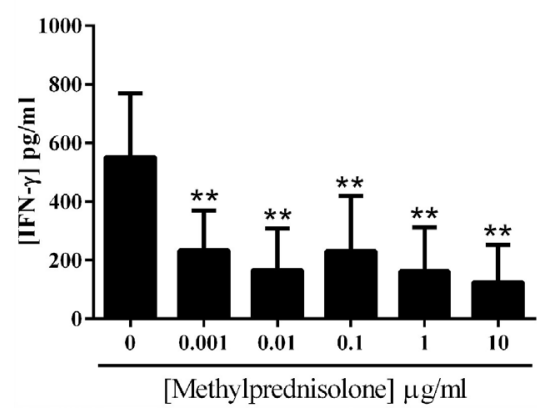

IL-6

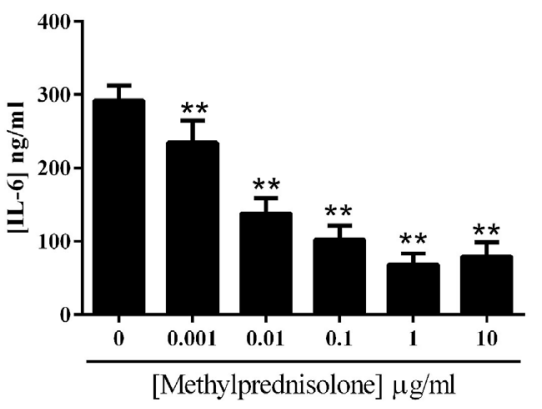

IL-10

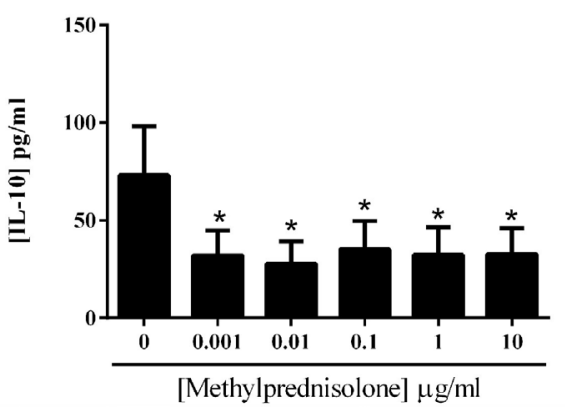

IL-1 $\beta$

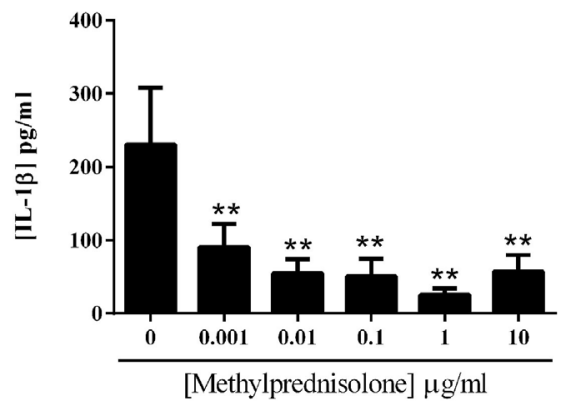

FIGURE 2 | Effect of the dose-response of methylprednisolone on cytokine production. Healthy PBMC activated by PHA (5 $\mu$ g/ml) were pre-incubated or not with different doses of methylprednisolone. Then, PBMC were cocultured with RA synoviocytes at a ratio $5: 1$ for $48 \mathrm{~h}$. The production of IL-17, IL-6, IL-1 $\beta$, IFN- $\gamma$, and IL-10 in cell supernatants was measured by enzyme-linked immunosorbent assay (ELISA). ${ }^{*} p \leq 0.05$. Results are represented as mean \pm SEM, $n=8$ experiments from six different RA patients.

$\mathrm{ml}$, Figure 3B). The IFN- $\gamma$ secretion was significantly reduced with $10 \mu \mathrm{g} / \mathrm{ml}(340.1 \pm 105.1$ vs. $532.0 \pm 163.9 \mathrm{pg} / \mathrm{ml}, p=0.03$, Figure 3B) but without reaching significance with $100 \mu \mathrm{g} / \mathrm{ml}$ $(370.2 \pm 137.0$ vs. $532.0 \pm 163.9 \mathrm{pg} / \mathrm{ml}, p=0.09$, Figure $3 \mathrm{~B})$, suggesting that high dose is not necessarily more efficient. The production of IL-10 was also significantly decreased by the addition of Tocilizumab $(37.9 \pm 12.6$ vs. $62.8 \pm 17.5 \mathrm{pg} / \mathrm{ml}$, for $10 \mu \mathrm{g} /$ $\mathrm{ml} ; 27.1 \pm 9.2$ vs. $62.8 \pm 17.5 \mathrm{pg} / \mathrm{ml}$, for $100 \mu \mathrm{g} / \mathrm{ml}, p=0.002$, Figure 3B).

Two biotherapies targeting specifically cells were also tested, Abatacept and Rituximab. Abatacept is a fusion protein (CTLA4-Ig) which interacts with B7 (ligand of CD28 which is a T cell activation molecule). The addition of Abatacept did not affect IL-17 and IL-6 secretion at $10 \mu \mathrm{g} / \mathrm{ml}(96.1 \pm 25.8 \mathrm{vs.} 94.8 \pm 26.1 \mathrm{pg} / \mathrm{ml}$ for IL-17; $309.5 \pm 42.1$ vs. $321.1 \pm 30.1 \mathrm{ng} / \mathrm{ml}$ for IL-6, Figure $3 C$ ) and at $100 \mu \mathrm{g} / \mathrm{ml}(83.2 \pm 24.5$ vs. $94.8 \pm 26.1 \mathrm{pg} / \mathrm{ml}$ for IL-17; $291.9 \pm 40.6$ vs. $321.1 \pm 30.1 \mathrm{ng} / \mathrm{ml}$ for IL-6, Figure $3 \mathrm{C})$. The production of IL-1 $\beta$ was significantly decreased by about $45 \%$, without a dose-effect $(143.1 \pm 40.4$ vs. $250.7 \pm 66.7 \mathrm{pg} / \mathrm{ml}$, for $10 \mu \mathrm{g} / \mathrm{ml} ; 132.0 \pm 40.5$ vs. $250.7 \pm 66.7 \mathrm{pg} / \mathrm{ml}$, for $100 \mu \mathrm{g} / \mathrm{ml}$, $p=0.002$, Figure 3C). IFN- $\gamma$ secretion was altered in a dosedependent pattern, as there was a significant decrease between 10 and $100 \mu \mathrm{g} / \mathrm{ml}(356.6 \pm 123.4 \mathrm{vs} .274 .7 \pm 95.2 \mathrm{pg} / \mathrm{ml}$, respectively, $p=0.04$, vs. $532.0 \pm 163.9 \mathrm{pg} / \mathrm{ml}$ for the control, Figure $3 \mathrm{C}$ ). IL-10 was decreased only with the higher dose of $100 \mu \mathrm{g} / \mathrm{ml}$ $(48.9 \pm 13.1$ vs. $62.8 \pm 17.5 \mathrm{pg} / \mathrm{ml}, p=0.03$, Figure $3 \mathrm{C})$.
Rituximab is a monoclonal antibody against CD20. As observed in Figure 3D, Rituximab had no effect on the secretion of IL-17, IL-6, and IL-10. The concentration of $10 \mu \mathrm{g} / \mathrm{ml}$ decreased significantly IL-1 $\beta$ production $(188.8 \pm 60.6$ vs. $250.7 \pm 66.7 \mathrm{pg} /$ $\mathrm{ml}, p=0.04)$ and also IFN- $\gamma$ secretion (370.2 \pm 137.0 vs. $532.0 \pm 163.9 \mathrm{pg} / \mathrm{ml}, p=0.02)$. At $100 \mu \mathrm{g} / \mathrm{ml}$, their production was not significantly decreased and as for Tocilizumab, this suggests that increasing the dose may not be necessary and even could have an opposite effect.

In summary, a global inhibitory effect of all biotherapies was observed but with differences between treatments. Infliximab and Tocilizumab had a higher and broader effect than Abatacept and Rituximab. This could be explained by the broader effect of Infliximab and Tocilizumab acting on cytokines and their receptors contrasting with the cell specificity of Abatacept and Rituximab.

\section{Effects of Various Anti-TNF Comparisons}

Various inhibitors of TNF are currently used with different modes of action. Infliximab was compared to two other TNF inhibitors, Etanercept, a soluble receptor, and Adalimumab, a monoclonal antibody like Infliximab. As observed in Figure 4, at both concentrations, only Adalimumab decreased significantly the secretion of IL-17 by about $30 \%$ (70.1 \pm 24.0 vs. $99.2 \pm 28.4 \mathrm{pg} /$ $\mathrm{ml}$ for $10 \mu \mathrm{g} / \mathrm{ml}$; and $67.1 \pm 22.0 \mathrm{vs.} 99.2 \pm 28.4 \mathrm{pg} / \mathrm{ml}$ for $100 \mu \mathrm{g} /$ $\mathrm{ml}, p=0.008$ ). The three biotherapies had a similar effect on IL-6 


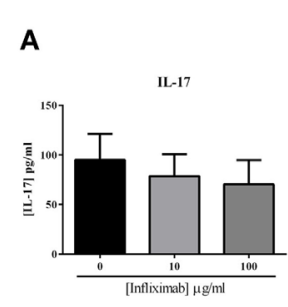

Infliximab

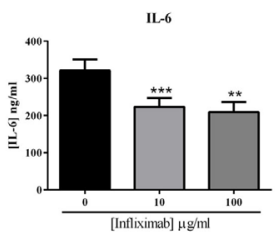

IL-10
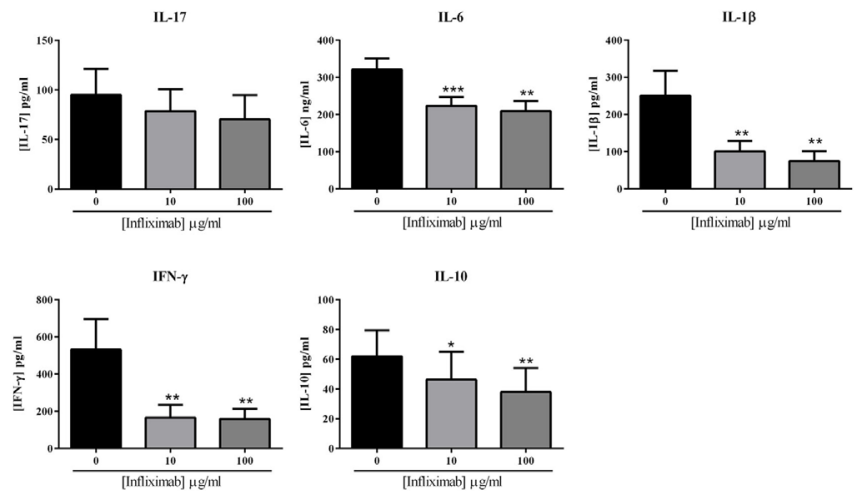

B

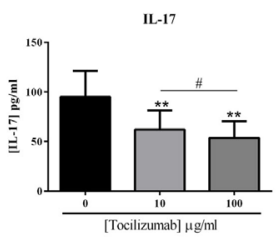

IFN- $\gamma$
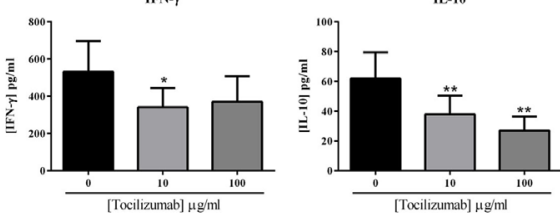

D
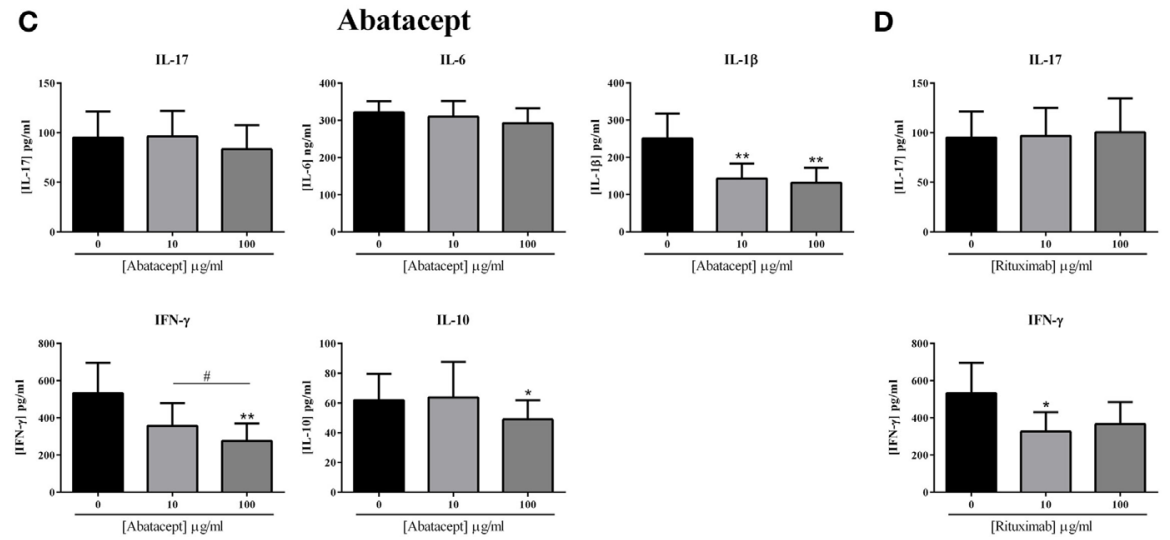

IFN-y

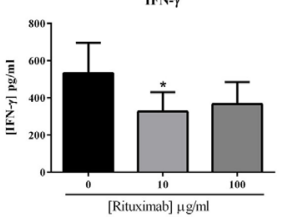

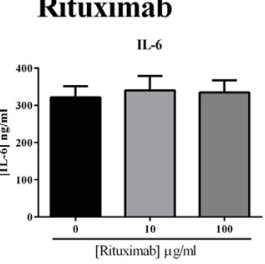

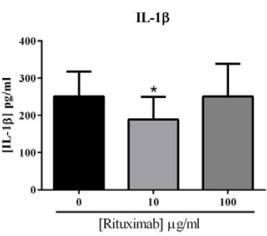

Tocilizumab

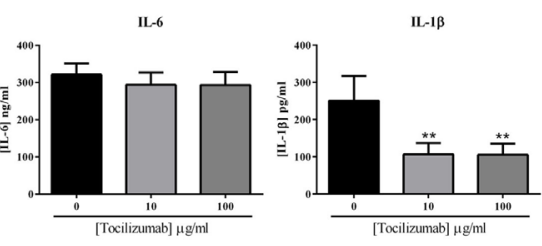

IL-10

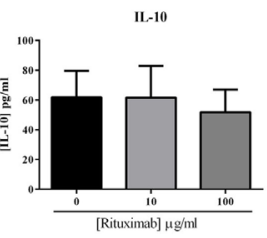

FIGURE 3 | Effect of biotherapies on cytokine production. Healthy activated-PBMC were pre-incubated or not with two doses of biotherapies, 10 or $100 \mu \mathrm{g} / \mathrm{ml}$ and cocultured with RA synoviocytes at a ratio 5:1 for $48 \mathrm{~h}$. Infliximab (A), Tocilizumab (B), Abatacept (C), and Rituximab (D) were tested. After 48 h, the production of IL-17, IL-6, IL-1 $\beta$, IFN- $\gamma$, and IL-10 in cell supernatants was measured by ELISA. ${ }^{*} p \leq 0.05$. Results are represented as mean \pm SEM, $n=11$ experiments from six different RA patients.

and IFN- $\gamma$, with an inhibition by about 30 and $70 \%$, respectively, with no clear dose effect (Figure 4). For IL-1 $\beta$, Infliximab was the most potent at both concentrations of the three inhibitors $(51.8 \pm 15.8$ vs. $230.3 \pm 70.3 \mathrm{pg} / \mathrm{ml}$ for Infliximab, $p=0.004$; $133.0 \pm 49.1$ vs. $230.3 \pm 70.3 \mathrm{pg} / \mathrm{ml}$ for Etanercept, $p=0.004$; and $138.4 \pm 52.0$ vs. $230.3 \pm 70.3 \mathrm{pg} / \mathrm{ml}$ for Adalimumab, $p=0.004)$. The three anti-TNF inhibited significantly the IL-10 production, without a dose-effect. A difference between the three biotherapies was observed, significantly only at $10 \mu \mathrm{g} / \mathrm{ml}$. Infliximab decreased less IL-10 production $(47.0 \pm 20.7$ vs. $63.1 \pm 19.3 \mathrm{pg} /$ $\mathrm{ml}$ for $10 \mu \mathrm{g} / \mathrm{ml}, p=0.07$; and $39.4 \pm 17.9$ vs. $63.1 \pm 19.3 \mathrm{pg} / \mathrm{ml}$ for $100 \mu \mathrm{g} / \mathrm{ml}, p=0.004)$, followed by Etanercept $(31.2 \pm 14.5$ vs. $63.1 \pm 19.3 \mathrm{pg} / \mathrm{ml}$ for $10 \mu \mathrm{g} / \mathrm{ml}, p=0.03$; and $25.8 \pm 15.5$ vs. $63.1 \pm 19.3 \mathrm{pg} / \mathrm{ml}$ for $100 \mu \mathrm{g} / \mathrm{ml}, p=0.008$ ); and the most inhibitory effect was obtained with Adalimumab (18.7 \pm 9.0 vs. $63.1 \pm 19.3 \mathrm{pg} / \mathrm{ml}$ for $10 \mu \mathrm{g} / \mathrm{ml}, p=0.004$; and $18.9 \pm 9.9 \mathrm{vs}$. $63.1 \pm 19.3 \mathrm{pg} / \mathrm{ml}$ for $100 \mu \mathrm{g} / \mathrm{ml}, p=0.004)$. Overall, the three anti-TNF displayed a similar effect. Nevertheless, Infliximab was the more potent on IL- $1 \beta$ inhibition and less than the others on IL-10 secretion.

\section{Combination of MP and Biotherapies}

The effect of treatment combination is not well understood in patients, and thus the basis for combining drugs remains unclear. The effect of MP and biotherapies, alone or in combination, was compared. The lowest effective doses of MP, $0.01 \mu \mathrm{g} / \mathrm{ml}$ and of biotherapies, $10 \mu \mathrm{g} / \mathrm{ml}$, were used alone or in combination to evaluate their impact on cytokine production. MP alone inhibited significantly IL-17 production (58.9 \pm 23.4 vs. $94.8 \pm 26.1 \mathrm{pg} /$ $\mathrm{ml}, p=0.02$, Figure 5A) as Tocilizumab alone $(62.0 \pm 19.4$ vs. $94.8 \pm 26.1 \mathrm{pg} / \mathrm{ml}, p=0.004$, Figure 5A). Infliximab, Abatacept, and Rituximab alone did not inhibit IL-17 production (Figure 5A). In combination, the inhibitory effect of MP and Tocilizumab was not increased and the inhibition was still around $40 \%(56.5 \pm 20.6$ vs. $94.8 \pm 26.1 \mathrm{pg} / \mathrm{ml}, p=0.004$, Figure $5 \mathbf{A})$. The combination of MP and Infliximab or Abatacept tended to increase IL-17 production compared to MP alone (73.3 \pm 20.8 and $85.7 \pm 27.8 \mathrm{pg} / \mathrm{ml}$, respectively, vs. $58.9 \pm 23.4 \mathrm{pg} / \mathrm{ml}, p=0.07$, Figure 5A). The combination of MP and Rituximab significantly inhibited the MP effect and the level of IL-17 was similar to the control $(102.3 \pm 30.6$ vs. $94.8 \pm 26.1 \mathrm{pg} / \mathrm{ml}, p=0.03$, Figure $5 \mathbf{A})$. 


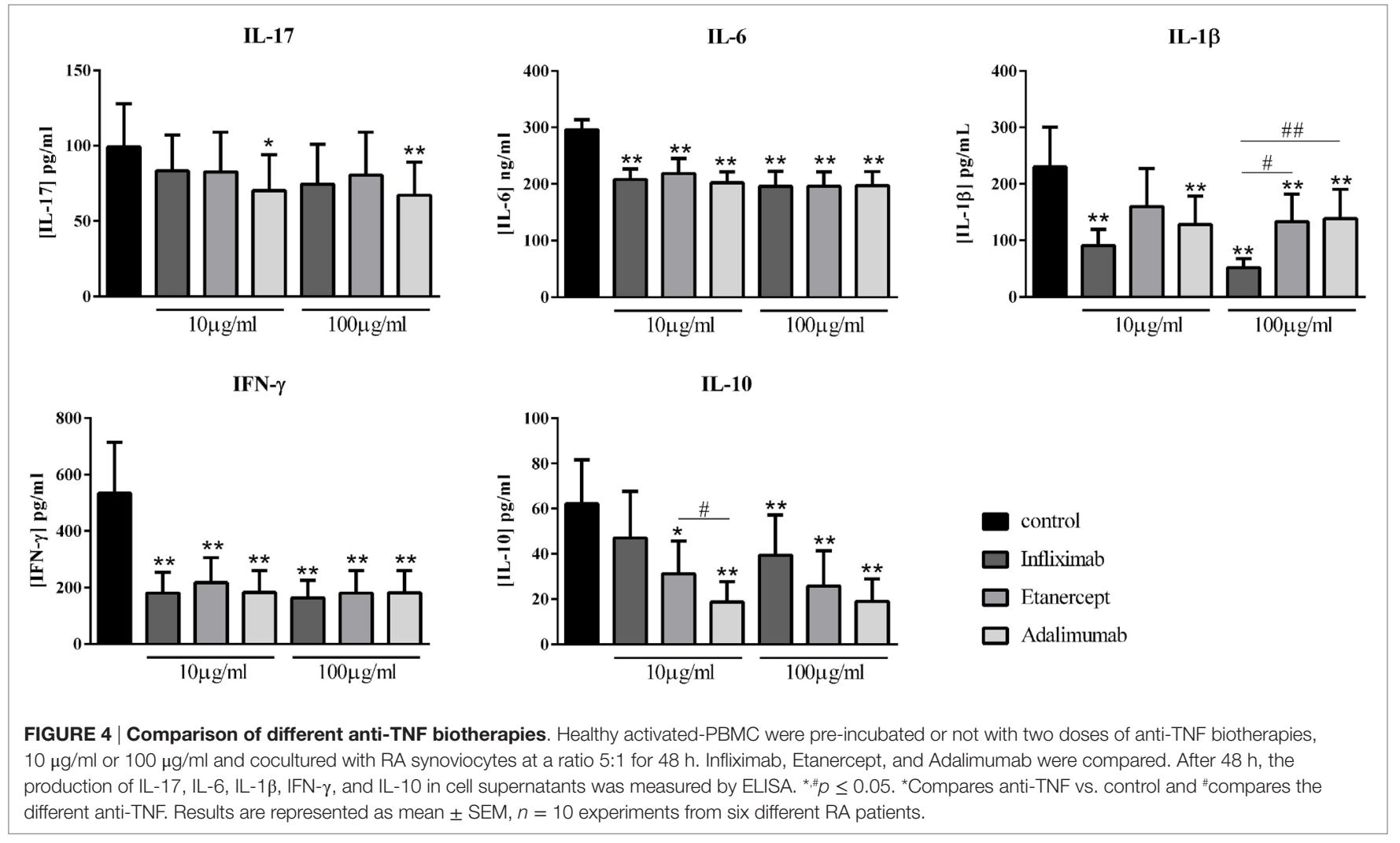

A

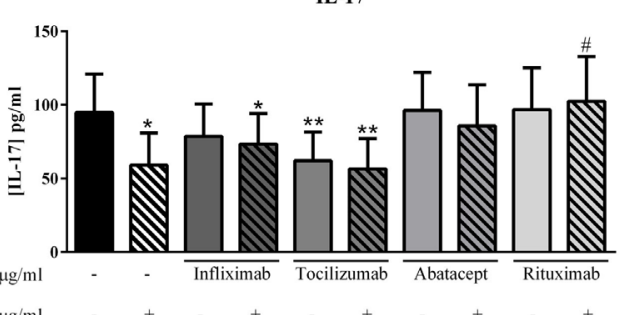

Methylprednisolone $0.01 \mu \mathrm{g} / \mathrm{ml}$

C

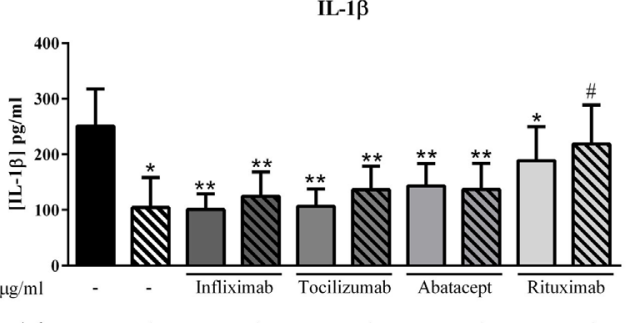

B

IL-6

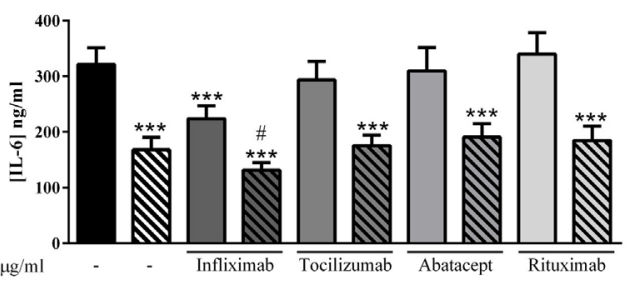

D

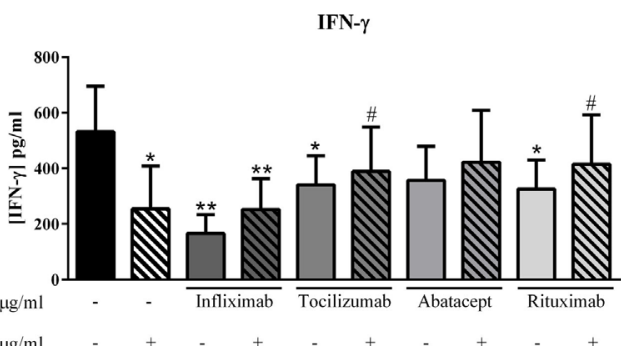

Methylprednisolone $0.01 \mu \mathrm{g} / \mathrm{ml}$

FIGURE 5 | Effect of the combination of methylprednisolone and biotherapy on pro-inflammatory cytokine production. Healthy activated-PBMC were pre-incubated or not with methylprednisolone alone $(0.01 \mu \mathrm{g} / \mathrm{ml})$, biotherapy alone $(10 \mu \mathrm{g} / \mathrm{ml})$, or with the combination of both treatments. Then, PBMC were cocultured with RA synoviocytes at a ratio 5:1 for $48 \mathrm{~h}$. Infliximab (A), Tocilizumab (B), Abatacept, (C) and Rituximab (D) were tested. After 48 h, the production of IL-17, IL-6, IL-1 $\beta$, and IFN- $\gamma$ in cell supernatants was measured by ELISA. *,\# $p \leq 0.05$. *Compares with control and ${ }^{*}$ compares combination MP/biotherapy vs. MP alone. Results are represented as mean \pm SEM, $n=11$ experiments from six different RA patients.

For IL-6 secretion, MP and Infliximab alone decreased significantly IL-6 secretion compared to control $(167.7 \pm 21.0 \mathrm{pg} / \mathrm{ml}$ and $78.5 \pm 22.1 \mathrm{pg} / \mathrm{ml}$, respectively, vs. $321.1 \pm 30.1 \mathrm{pg} / \mathrm{ml}, p=0.001$
Figure 5B); and the combination of both increased significantly the inhibitory effect compared to MP alone (131.3 \pm 13.6 vs. $167.7 \pm 21.0 \mathrm{pg} / \mathrm{ml}, p=0.04$, Figure 5B). The combination of MP 


\section{IL-10}

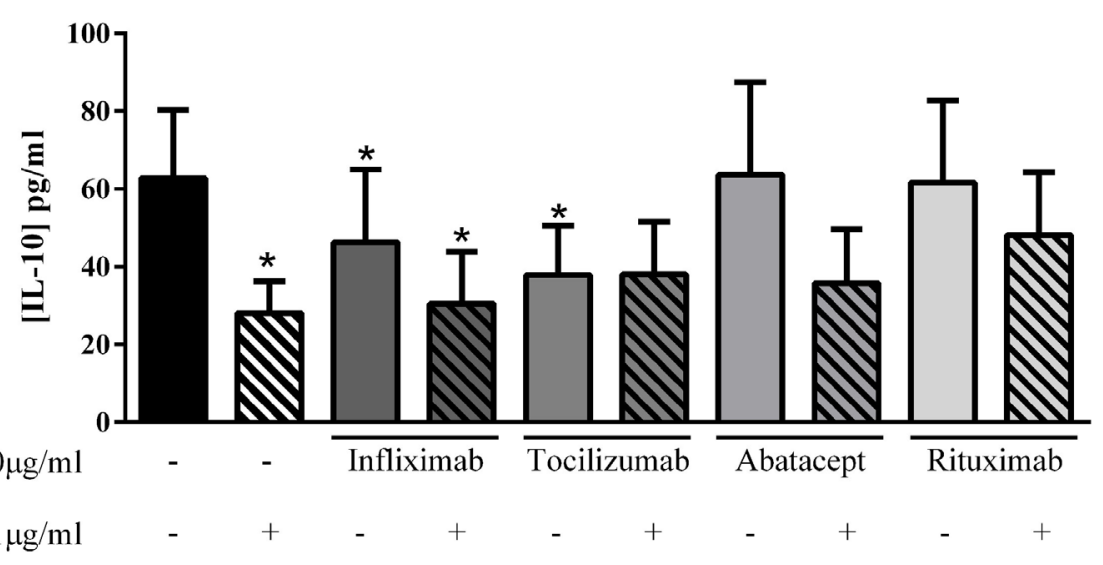

FIGURE 6 | Effect of the combination of methylprednisolone and biotherapy on IL-10 production. Healthy activated-PBMC were pre-incubated or not with methylprednisolone alone $(0.01 \mu \mathrm{g} / \mathrm{ml})$, biotherapy alone $(10 \mu \mathrm{g} / \mathrm{ml})$, or with the combination of both treatments. Then, PBMC were cocultured with RA synoviocytes at a ratio of 5:1 for $48 \mathrm{~h}$. Infliximab, Tocilizumab, Abatacept, and Rituximab were tested. After $48 \mathrm{~h}$, the production of IL-10 in cell supernatants was measured by ELISA. * $p \leq 0.05$. *Compares with control. Results are represented as mean \pm SEM, $n=10$ experiments from six different RA patients.

with other biotherapies (Tocilizumab, Abatacept, and Rituximab) did not change the decreased IL-6 production induced by MP alone (Figure 5B).

IL-1 $\beta$ production was decreased in a similar way between MP alone, Infliximab, Tocilizumab, or Abatacept alone and the combination of both (Figure 5C). Nevertheless, Rituximab alone inhibited IL-1 $\beta$ secretion but to a less extent that MP alone, compared to control $(188.8 \pm 60.6 \mathrm{pg} / \mathrm{ml}, p=0.04$, and $104.5 \pm 59.2 \mathrm{pg} / \mathrm{ml}, p=0.002$, respectively, vs. $250.7 \pm 77.8 \mathrm{pg} /$ $\mathrm{ml}$ ); and the combination of both canceled the large inhibitory effect of MP alone (218.4 \pm 70.4 vs. $104.5 \pm 59.2 \mathrm{pg} / \mathrm{ml}, p=0.03$, Figure 5C).

Except Abatacept, biotherapies (Infliximab, Tocilizumab and Rituximab) or MP alone decreased significantly the production of IFN- $\gamma$ compared to control (Figure 5D). The combination of MP and Infliximab led to a similar inhibition than MP alone $(252.2 \pm 110.6$ vs. $254.2 \pm 169.2 \mathrm{pg} / \mathrm{ml}$ compared to $532.0 \pm 163.9 \mathrm{pg} / \mathrm{ml}$ for control, Figure 5D). The combination of MP with Tocilizumab and Rituximab significantly reduced the inhibition of IFN- $\gamma$ secretion compared to MP alone $(389.3 \pm 159.4 \mathrm{pg} / \mathrm{ml}, p=0.03$, and $415.1 \pm 178.1 \mathrm{pg} / \mathrm{ml}, p=0.01$, respectively, vs. $254.2 \pm 169.2 \mathrm{pg} / \mathrm{ml}$, Figure $5 \mathrm{D}$ ), and it was the same tendency for the combination of MP and Abatacept $(p=0.08$, Figure 5D).

Herein, the results showed that the combination even at low doses did not necessarily result in an additional effect on the inhibition of pro-inflammatory cytokine production.

\section{Effect on IL-10 Secretion}

Given some unexpected results on pro-inflammatory cytokines with the combination of MP and biotherapy, the next step was to detect a potential effect on the anti-inflammatory cytokine IL-10. The dose of $0.01 \mu \mathrm{g} / \mathrm{ml}$ of MP alone decreased IL-10 production compared to control $(28.0 \pm 9.1$ vs. $62.8 \pm 17.5 \mathrm{pg} / \mathrm{ml}$, $p=0.01$, Figure 6). Infliximab and Tocilizumab alone inhibited significantly the IL-10 secretion $(46.3 \pm 18.7 \mathrm{pg} / \mathrm{ml}, p=0.05$, and $37.9 \pm 12.6 \mathrm{pg} / \mathrm{ml}, p=0.002$, respectively, vs. $62.8 \pm 17.5 \mathrm{pg} / \mathrm{ml}$, Figure 6), while Abatacept and Rituximab did not affect the IL-10 level compared to control $(63.8 \pm 23.7 \mathrm{pg} / \mathrm{ml}$ and $61.6 \pm 21.2 \mathrm{pg} /$ $\mathrm{ml}$, respectively, vs. $62.8 \pm 17.5 \mathrm{pg} / \mathrm{ml}$, Figure 6). In the presence of the combination of MP and biotherapy, the IL-10 level was lower than control but higher than MP alone, mainly with Rituximab, without reaching significance $(48.1 \pm 16.3$ vs. $28.0 \pm 9.1 \mathrm{pg} / \mathrm{ml}$, $p=0.3$, Figure 6). These results indicated that the beneficial effect of combination of MP and biotherapy could come from a reduction of the inhibitory effect of MP on IL-10 production.

\section{DISCUSSION}

In this study, the interest was focused on the effects of steroids and biotherapies alone and combined on cytokine production resulting from cell interactions between mesenchymal cells and immune cells.

Steroids are very effective anti-inflammatory drugs but the adverse effects limit their use. There is no doubt that steroids present a strong potential for frequent and serious side effects, increasing with longer use and higher dose (18). Side effects of chronic steroid therapy are dose-related. At a low-dose $(<7.5 \mathrm{mg} /$ day), many studies suggest that steroid treatment is relatively safe in RA $(19,20)$, and even a very low dose $(<5 \mathrm{mg} / \mathrm{ml})$, can be sufficient to maintain remission without severe adverse events (21) but a better clinical response (22-25). To identify their effects at the cellular level, an in vitro model based on interactions between mesenchymal cells and PBMC was used to mimic the in vivo inflammatory state. A dose-response with MP was done to evaluate its effects on cytokine production. The production of pro-inflammatory cytokines was clearly inhibited by the addition of MP in coculture with differences between cytokines. If IL-17 
and IL- 6 production decreased according to a dose-response, IL- $1 \beta$ and IFN- $\gamma$ secretion was already inhibited with the lowest concentration of $0.001 \mu \mathrm{g} / \mathrm{ml}$. A low dose of MP appears sufficient to induce an inhibitory effect on pro-inflammatory cytokine production. Furthermore, from $10 \mu \mathrm{g} / \mathrm{ml}$ the cytokine production, notably IL-6 and IL-1 $\beta$, appeared to increase compared to $1 \mu \mathrm{g} /$ $\mathrm{ml}$. In the clinic, this would suggest high dosage of MP might not be needed to obtain its anti-inflammatory effect through cytokine inhibition and that high doses could have the opposite effect. In addition, the presence of MP even at the lowest dose also inhibited the secretion of IL-10. This may explain the increased risk of infection for the treated patients.

The use of biotherapies during chronic inflammatory diseases, such as RA, has been a major step in improved care. The benefits on clinical symptoms are well established, while the effect at cellular levels is less documented. Our in vitro system demonstrated in previous studies that cell interactions between mesenchymal cells including synoviocytes from RA patients or skin fibroblasts from psoriatic patients and immune cells resulted in massive pro-inflammatory cytokine production as observed in the in vivo situation $(14,15)$. Our system was used to evaluate the effect of current biotherapies at the cytokine production level.

TNF is a pro-inflammatory cytokine clearly involved in the pathogenesis of RA $(1,26)$, notably by stimulating synoviocytes to produce IL-6. As expected, TNF inhibition led to a decreased production of IL- 6 which is also a pro-inflammatory cytokine involved in the activation of $\mathrm{T}$ cell differentiation. The decrease of IL- 6 level could result in the decreased IL- $1 \beta$ and IFN- $\gamma$ levels. The most used anti-TNF treatments are Infliximab, Etanercept, and Adalimumab, and some studies showed differences in efficacy and adherence between them $(27,28)$. When compared at the cellular level, the three therapies displayed a rather similar inhibitory effect on pro-inflammatory cytokine production. The major difference appeared on IL-10 production, with Infliximab inhibiting less IL-10 production compared to the two others.

Two-thirds of the RA patients respond to anti-TNF leaving space for other treatment options (27). Tocilizumab is a recombinant humanized monoclonal antibody against the IL-6 receptor (IL-6R), preventing IL-6 binding to both membranous and soluble IL-6R $(29,30)$. In our in vitro system, Tocilizumab decreased significantly IL- $1 \beta$ and IL-17 secretion $(26,31,32)$. Both IL- 6 and IL- $1 \beta$ are involved in the Th17 differentiation. Thus, the inhibition of IL-6R followed by the decrease of IL- $1 \beta$ could explain the observed inhibition of IL-17 secretion. The secretion of IL- 6 was not decreased by the addition of Tocilizumab but such detection is complex. Indeed, in RA patients, the serum level of IL-6 increases after Tocilizumab administration, as IL-6 does not bind its receptor (33). Nevertheless, its signaling pathway is well

\section{REFERENCES}

1. Firestein GS. Evolving concepts of rheumatoid arthritis. Nature (2003) 423:356-61. doi:10.1038/nature01661

2. van der Goes MC, Jacobs JW, Bijlsma JW. The value of glucocorticoid co-therapy in different rheumatic diseases - positive and adverse effects. Arthritis Res Ther (2014) 16(Suppl 2):S2. doi:10.1186/ar4686 inhibited as confirmed by the decreased production of CRP in patients.

In addition to cytokine inhibition, other biotherapies target cells. In this way, two other biotherapies, Abatacept and Rituximab were tested on cytokine production. Abatacept is a fusion protein of the extracellular domain of cytotoxic T-lymphocyte-associated protein 4 (CTLA-4) and the Fc region of IgG1. It prevents T cell activation by CD28 by increasing the inhibitory effect of CTLA-4 on $\mathrm{T}$ cell activation (34). In our in vitro system, the major inhibited cytokine was IL- $1 \beta$. The decrease of IFN- $\gamma$ production could be explained by the direct effect of Abatacept on T cell activation. In addition, IL-1 $\beta$ is involved in IFN- $\gamma$ secretion by $\mathrm{T}$ cells (35, 36) and NK cells (37). Thus, Abatacept may have a direct effect on $\mathrm{T}$ cell activation and an indirect effect by inhibiting IL-1 $\beta$ production.

Rituximab is directed against CD20 and induces the death of B cells (38). Herein, Rituximab decreased only IL-1 $\beta$ and IFN- $\gamma$ production, at low dose. As Rituximab acts directly on B cells, it could be interesting to study the in vitro effect on immunoglobulin production. Indeed, patients positive for anti-citrullinated protein antibodies (ACPA) appear to respond better to Rituximab (39-41).

Steroids and biotherapies are two different ways to diminish inflammation, by reducing cytokine production. The first conclusion is that high doses were not more efficient than low doses, for both steroids and biotherapies. The effect of their combination each at low dose is more complex. Addition of a biotherapy seemed to reduce the effect of MP alone. At the same time, the combination reduced the inhibitory effect on IL-10 production of the two treatments used alone. At the end, the combination may increase the net anti-inflammatory effects of IL-10 with a suppressor effect on numerous pro-inflammatory cytokines, such as TNF, IL-1 $\beta$, or IL- 6 , all involved in RA pathogenesis. The next step of these studies will be to evaluate this time the effects of MTX alone and combined with biotherapies, as done routinely in patients with RA and other inflammatory diseases.

\section{AUTHOR CONTRIBUTIONS}

$\mathrm{MN}$ carried out the experiments and drafted the manuscript. NN-T participated in the experiments. PM conceived the study and reviewed the manuscript. All the authors read and approved the final manuscript.

\section{FUNDING}

$\mathrm{MN}$ is supported by the Institut Universitaire de France. NN-T is supported by the IHU prometteur OPERA. PM is a senior member of and supported by the Institut Universitaire de France.

3. Coutinho AE, Chapman KE. The anti-inflammatory and immunosuppressive effects of glucocorticoids, recent developments and mechanistic insights. $\mathrm{Mol}$ Cell Endocrinol (2011) 335:2-13. doi:10.1016/j.mce.2010.04.005

4. Barnes PJ. How corticosteroids control inflammation: quintiles prize lecture 2005. Br J Pharmacol (2006) 148:245-54. doi:10.1038/sj.bjp.0706736

5. Barnes PJ, Adcock IM. Glucocorticoid resistance in inflammatory diseases. Lancet (2009) 373:1905-17. doi:10.1016/S0140-6736(09)60326-3 
6. Bijlsma JW, Jacobs JW. Methotrexate: still the anchor drug in RA treatment. Joint Bone Spine (2009) 76:452-4. doi:10.1016/j.jbspin.2009.05.007

7. Lopez-Olivo MA, Siddhanamatha HR, Shea B, Tugwell P, Wells GA, SuarezAlmazor ME. Methotrexate for treating rheumatoid arthritis. Cochrane Database Syst Rev (2014) 6:CD000957. doi:10.1002/14651858.CD000957. pub2

8. Singh JA, Furst DE, Bharat A, Curtis JR, Kavanaugh AF, Kremer JM. 2012 update of the 2008 American College of Rheumatology recommendations for the use of disease-modifying antirheumatic drugs and biologic agents in the treatment of rheumatoid arthritis. Arthritis Care Res (Hoboken) (2012) 64:625-39. doi:10.1002/acr.21641

9. Fleischmann RM. Safety of biologic therapy in rheumatoid arthritis and other autoimmune diseases: focus on rituximab. Semin Arthritis Rheum (2009) 38:265-80. doi:10.1016/j.semarthrit.2008.01.001

10. Furst DE. The risk of infections with biologic therapies for rheumatoid arthritis. Semin Arthritis Rheum (2010) 39:327-46. doi:10.1016/ j.semarthrit.2008.10.002

11. Cho ML, Yoon CH, Hwang SY, Park MK, Min SY, Lee SH, et al. Effector function of type II collagen-stimulated $\mathrm{T}$ cells from rheumatoid arthritis patients: cross-talk between T cells and synovial fibroblasts. Arthritis Rheum (2004) 50:776-84. doi:10.1002/art.20106

12. Miranda-Carus ME, Balsa A, Benito-Miguel M, Perez de Ayala C, MartinMola E. IL-15 and the initiation of cell contact-dependent synovial fibroblast-T lymphocyte cross-talk in rheumatoid arthritis: effect of methotrexate. J Immunol (2004) 173:1463-76. doi:10.4049/jimmunol.173.2.1463

13. Tran CN, Lundy SK, White PT, Endres JL, Motyl CD, Gupta R, et al. Molecular interactions between $\mathrm{T}$ cells and fibroblast-like synoviocytes: role of membrane tumor necrosis factor-alpha on cytokine-activated T cells. Am J Pathol (2007) 171:1588-98. doi:10.2353/ajpath.2007.070004

14. Noack M, Ndongo-Thiam N, Miossec P. Interaction among activated lymphocytes and mesenchymal cells through podoplanin is critical for a high IL-17 secretion. Arthritis Res Ther (2016) 18:148. doi:10.1186/s13075-0161046-6

15. Noack M, Ndongo-Thiam N, Miossec P. Role of podoplanin in the high interleukin-17A secretion resulting from interactions between activated lymphocytes and psoriatic skin-derived mesenchymal cells. Clin Exp Immunol (2016) 186:64-74. doi:10.1111/cei.12830

16. Aletaha D, Neogi T, Silman AJ, Funovits J, Felson DT, Bingham CO III, et al. 2010 Rheumatoid arthritis classification criteria: an American College of Rheumatology/European League Against Rheumatism collaborative initiative. Arthritis Rheum (2010) 62:2569-81. doi:10.1002/art.27584

17. Eljaafari A, Tartelin ML, Aissaoui H, Chevrel G, Osta B, Lavocat F. Bone marrow-derived and synovium-derived mesenchymal cells promote Th17 cell expansion and activation through caspase 1 activation: contribution to the chronicity of rheumatoid arthritis. Arthritis Rheum (2012) 64:2147-57. doi:10.1002/art.34391

18. Huscher D, Thiele K, Gromnica-Ihle E, Hein G, Demary W, Dreher R. Doserelated patterns of glucocorticoid-induced side effects. Ann Rheum Dis (2009) 68:1119-24. doi:10.1136/ard.2008.092163

19. Toms TE, Panoulas VF, Douglas KM, Griffiths HR, Kitas GD. Lack of association between glucocorticoid use and presence of the metabolic syndrome in patients with rheumatoid arthritis: a cross-sectional study. Arthritis Res Ther (2008) 10:R145. doi:10.1186/ar2578

20. Da Silva JA, Jacobs JW, Kirwan JR, Boers M, Saag KG, Ines LB, et al. Safety of low dose glucocorticoid treatment in rheumatoid arthritis: published evidence and prospective trial data. Ann Rheum Dis (2006) 65:285-93. doi:10.1136/ $\operatorname{ard} .2005 .038638$

21. Pincus T, Sokka T, Castrejon I, Cutolo M. Decline of mean initial prednisone dosage from 10.3 to $3.6 \mathrm{mg} /$ day to treat rheumatoid arthritis between 1980 and 2004 in one clinical setting, with long-term effectiveness of dosages less than $5 \mathrm{mg} /$ day. Arthritis Care Res (Hoboken) (2013) 65:729-36. doi:10.1002/ acr.21899

22. Hansen M, Podenphant J, Florescu A, Stoltenberg M, Borch A, Kluger E, et al. A randomised trial of differentiated prednisolone treatment in active rheumatoid arthritis. Clinical benefits and skeletal side effects. Ann Rheum Dis (1999) 58:713-8. doi:10.1136/ard.58.11.713

23. van Everdingen AA, Jacobs JW, Siewertsz Van Reesema DR, Bijlsma JW. Lowdose prednisone therapy for patients with early active rheumatoid arthritis: clinical efficacy, disease-modifying properties, and side effects: a randomized, double-blind, placebo-controlled clinical trial. Ann Intern Med (2002) 136:1-12. doi:10.7326/0003-4819-136-1-200201010-00006

24. Kirwan JR, Bijlsma JW, Boers M, Shea BJ. Effects of glucocorticoids on radiological progression in rheumatoid arthritis. Cochrane Database Syst Rev (2007) 1:CD006356. doi:10.1002/14651858.CD006356

25. Jacobs JW, van Everdingen AA, Verstappen SM, Bijlsma JW. Followup radiographic data on patients with rheumatoid arthritis who participated in a two-year trial of prednisone therapy or placebo. Arthritis Rheum (2006) 54:1422-8. doi:10.1002/art.21809

26. Choy EH, Panayi GS. Cytokine pathways and joint inflammation in rheumatoid arthritis. N Engl JMed (2001) 344:907-16. doi:10.1056/ NEJM200103223441207

27. Hetland ML, Christensen IJ, Tarp U, Dreyer L, Hansen A, Hansen IT. Direct comparison of treatment responses, remission rates, and drug adherence in patients with rheumatoid arthritis treated with adalimumab, etanercept, or infliximab: results from eight years of surveillance of clinical practice in the nationwide Danish DANBIO registry. Arthritis Rheum (2010) 62:22-32. doi:10.1002/art.27227

28. Kievit W, Adang EM, Fransen J, Kuper HH, van de Laar MA, Jansen TL, et al. The effectiveness and medication costs of three anti-tumour necrosis factor alpha agents in the treatment of rheumatoid arthritis from prospective clinical practice data. Ann Rheum Dis (2008) 67:1229-34. doi:10.1136/ ard.2007.083675

29. Nishimoto N, Kishimoto T. Humanized antihuman IL-6 receptor antibody, tocilizumab. Handb Exp Pharmacol (2008) 181:151-60. doi:10.1007/ 978-3-540-73259-4_7

30. Navarro-Millan I, Singh JA, Curtis JR. Systematic review of tocilizumab for rheumatoid arthritis: a new biologic agent targeting the interleukin-6 receptor. Clin Ther (2012) 34(788-802):e783. doi:10.1016/j.clinthera.2012. 02.014

31. Miossec P, Kolls JK. Targeting IL-17 and TH17 cells in chronic inflammation. Nat Rev Drug Discov (2012) 11:763-76. doi:10.1038/nrd3794

32. McInnes IB, Schett G. Cytokines in the pathogenesis of rheumatoid arthritis. Nat Rev Immunol (2007) 7:429-42. doi:10.1038/nri2094

33. Nishimoto N, Terao K, Mima T, Nakahara H, Takagi N, Kakehi T. Mechanisms and pathologic significances in increase in serum interleukin-6 (IL-6) and soluble IL-6 receptor after administration of an anti-IL-6 receptor antibody, tocilizumab, in patients with rheumatoid arthritis and Castleman disease. Blood (2008) 112:3959-64. doi:10.1182/blood-2008-05-155846

34. Alegre ML, Fallarino F. Mechanisms of CTLA-4-Ig in tolerance induction. Curr Pharm Des (2006) 12:149-60. doi:10.2174/138161206775193046

35. Tominaga $K$, Yoshimoto $T$, Torigoe $K$, Kurimoto M, Matsui K, Hada T, et al. IL-12 synergizes with IL-18 or IL-1beta for IFN-gamma production from human T cells. Int Immunol (2000) 12:151-60. doi:10.1093/intimm/ 12.2.151

36. Zielinski CE, Mele F, Aschenbrenner D, Jarrossay D, Ronchi F, Gattorno M. Pathogen-induced human TH17 cells produce IFN-gamma or IL-10 and are regulated by IL-1beta. Nature (2012) 484:514-8. doi:10.1038/ nature 10957

37. Cooper MA, Fehniger TA, Ponnappan A, Mehta V, Wewers MD, Caligiuri MA. Interleukin-1beta costimulates interferon-gamma production by human natural killer cells. Eur J Immunol (2001) 31:792-801. doi:10.1002/1521-4141(200103)31:3<792::AID-IMMU792>3.0.CO;2-U

38. Weiner GJ. Rituximab: mechanism of action. Semin Hematol (2010) 47:115-23. doi:10.1053/j.seminhematol.2010.01.011

39. Chatzidionysiou K, Lie E, Nasonov E, Lukina G, Hetland ML, Tarp U, et al. Highest clinical effectiveness of rituximab in autoantibody-positive patients with rheumatoid arthritis and in those for whom no more than one previous TNF antagonist has failed: pooled data from 10 European registries. Ann Rheum Dis (2011) 70:1575-80. doi:10.1136/ard.2010.148759

40. Isaacs JD, Cohen SB, Emery P, Tak PP, Wang J, Lei G, et al. Effect of baseline rheumatoid factor and anticitrullinated peptide antibody serotype on rituximab clinical response: a meta-analysis. Ann Rheum Dis (2013) 72:329-36. doi:10.1136/annrheumdis-2011-201117

41. Cambridge G, Leandro MJ, Lahey LJ, Fairhead T, Robinson WH, Sokolove J. B cell depletion with rituximab in patients with rheumatoid arthritis: multiplex bead array reveals the kinetics of IgG and IgA antibodies to 
citrullinated antigens. J Autoimmun (2016) 70:22-30. doi:10.1016/j.jaut.2016. 03.010

Conflict of Interest Statement: The authors declare that the research was conducted in the absence of any commercial or financial relationships that could be construed as a potential conflict of interest.
Copyright $\odot 2016$ Noack, Ndongo-Thiam and Miossec. This is an open-access article distributed under the terms of the Creative Commons Attribution License (CC BY). The use, distribution or reproduction in other forums is permitted, provided the original author(s) or licensor are credited and that the original publication in this journal is cited, in accordance with accepted academic practice. No use, distribution or reproduction is permitted which does not comply with these terms. 